\title{
Dopamine-induced tyrosine phosphorylation of NR2B (Tyr1472) is essential for ERK1/2 activation and processing of novel taste information
}

\section{Orit David ', Iliana Barrera' , Adaikkan Chinnakkaruppan' , Hanoch Kaphzan', Takanobu Nakazawa ${ }^{2}$, Tadashi Yamamoto ${ }^{2}$ and Kobi Rosenblum ${ }^{1,3}$ *}

' Sagol Department of Neurobiology, University of Haifa, Haifa, Israel

${ }^{2}$ Division of Oncology, Institute of Medical Science, University of Tokyo, Tokyo, Japan

${ }^{3}$ Center for Gene Manipulation in the Brain, University of Haifa, Haifa, Israel

\section{Edited by:}

Bernard Attali, Tel Aviv University, Israel

\section{Reviewed by:}

Asya Rolls, Technion, Israel Technology Institute, Israel

Baojin Ding, University of

Massachusetts Medical School, USA

\section{*Correspondence:}

Kobi Rosenblum, Sagol Department of Neurobiology, University of Haifa, Mt. Carmel, Haifa 3498838, Israel e-mail: kobir@psy.haifa.ac.il
Understanding the heterosynaptic interaction between glutamatergic and neuromodulatory synapses is highly important for revealing brain function in health and disease. For instance, the interaction between dopamine and glutamate neurotransmission is vital for memory and synaptic plasticity consolidation, and it is known to converge on extracellular signal-regulated kinase (ERK)-MAPK signaling in neurons. Previous studies suggest that dopamine induces $\mathrm{N}$-methyl-D-aspartate (NMDA) receptor phosphorylation at the NR2B Y1472 subunit, influencing receptor internalization at the synaptic plasma membrane. However, it is unclear whether this phosphorylation is upstream to and/or necessary for ERK1/2 activation, which is known to be crucial for synaptic plasticity and memory consolidation. Here, we tested the hypothesis that tyrosine phosphorylation of NR2B at Y1472 is correlated with ERK1/2 activation by dopamine and necessary for it as well. We find that dopamine receptor D1, but not D2, activates ERK1/2 and leads to NR2BY1472 phosphorylation in the mature hippocampus and cortex. Moreover, our results indicate that NR2B Y1472 phosphorylation is necessary for ERK1/2 activation. Importantly, application of dopamine or the D1 receptor agonist SKF38393 to hippocampal slices from NR2B F1472 mutant mice did not result in ERK1/2 activation, suggesting this site is not only correlated with ERK1/2 activation by dopamine stimulation, but also necessary for it. In addition, NR2B F1472 mice show impairment in learning of attenuation of taste neophobia but not associative taste learning. Our study shows that the dopaminergic and glutamatergic transmission converge on the NMDA receptor itself, at the Y1472 site of the NR2B subunit, and that this convergence is essential for ERK $1 / 2$ activation in the mature brain and for processing new sensory information in the cortex.

Keywords: dopamine, acetylcholine, extracellular signal-regulated kinase (ERK), NR2B, memory, cortex, hippocampus

\section{INTRODUCTION}

Memory consolidation is enabled, at least in part, by heterosynaptic modulation of the glutamatergic input by neuromodulatory synapses in different brain areas (Bailey et al., 2000). One such interaction is the heterosynaptic modulation between the ionotropic glutamate receptor, $N$-methyl-D-aspartate (NMDA) receptor and metabotropic dopamine receptors. Interaction between glutamatergic and dopaminergic synapses in the mature hippocampus is important for modulation of longterm potentiation (LTP) and long-term memory in the CA1 region of the hippocampus (Frey etal., 1990, 1991; Matthies etal., 1997; Bailey etal., 2000). Blocking this interaction prevents or attenuates LTP (Frey etal., 1990, 1991; Huang and Kandel, 1995; Riedel etal., 2003). We have previously shown that dopamine and NMDA induce ERK1/2 activation in the mature hippocampus, and that the convergence of these two signaling pathways takes place on the NMDA receptor itself (Kaphzan et al., 2006, 2007). However, the detailed molecular mechanism underlying this convergence has been largely unexplored.

From a biochemical perspective, D1- and D2-type dopamine receptors activate MAPK cascades, such as ERK, p38, and JNK in neuronal as well as in non-neural cells (Yan et al., 1999; Valjent et al., 2000; Guerrero et al., 2002; Lee et al., 2006). Phosphorylation of the NR2B subunit of the NMDA receptor at Y1472 located at the intracellular c-terminal end of the protein is mediated by the Src-protein family of kinases (SFK; Grosshans et al., 2002). In addition, Fyn protein tyrosine kinase is required for NMDA receptor tyrosine phosphorylation (Dunah and Standaert, 2001; Dunah et al., 2004).

The NMDA receptor is involved in various aspects of synaptic plasticity induction and memory acquisition in different brain structures underlying different learning forms and potentiation paradigms (Bliss and Collingridge, 1993; Bear and Abraham, 1996; Kemp and Bashir, 2001). Phosphorylation of the NR2B subunit of the NMDA receptor at Y1472 is involved in maintenance of 
neuropathic pain (Abe et al., 2005). This phosphorylation is also required for both synaptic plasticity (Nakazawa et al., 2002, 2006) and learning paradigms such as fear conditioning (Nakazawa et al., 2006).

Numerous studies have shown the importance of the dopaminergic system, NR2B Y1472, and the ERK-MAPK pathway in novel taste learning and conditioned taste aversion (CTA, Berman et al., 2000; Swank, 2000; Belelovsky et al., 2005; Cannon et al., 2005; Elkobi et al., 2008; Barki-Harrington et al., 2009; Guzman-Ramos et al., 2010). However, it is unclear whether these molecular pathways are all linked together in this type of learning.

In the present study, we investigated the mechanisms underlying dopaminergic and glutamatergic synergistic activation of ERK-MAPK pathway via convergence on the NMDA receptor itself, in the mature hippocampus and cortex. We show that dopamine D1 receptor activation induces the Y1472 phosphorylation of NR2B via the Src protein kinase, and that this interaction is essential for cortical-dependent novel taste learning.

\section{MATERIALS AND METHODS ANIMALS}

Male Sprague-Dawley rats ( $\sim 60$ days old, 250-300 g), and C57BL/6 mice (20-22 g) were procured from Harlan (Harlan, Jerusalem, Israel). NR2B F1472 mutant mice lacking the Y1472 phosphorylation site by substituting Tyr-1472 (Y) with Phe-1472 (F) were given to us by Prof. Nakazawa and Prof. Yamamoto (Nakazawa et al., 2006). Animals were provided ad libitum with standard food and water and were maintained on a 12/12 h light/dark cycle. All experiments were approved by the Institutional Animal Care and Use Committee of the University of Haifa, and adequate measures were taken in order to minimize pain, in accordance with the guidelines laid down by the European Union and United States NIH, regarding the care and use of animals in experiments.

\section{PHARMACOLOGY}

For pharmacological manipulations: dopamine (20 $\mu \mathrm{M}, 10 \mathrm{~min})$ was co-applied with the antioxidant ascorbic acid $(1 \mathrm{mM})$; carbachol 2-[(aminocarbonyl)oxy]-N,N,N-trimethylethanaminium chloride); D(-)-APV (D-2-amino-5-phosphonovaleric acid $(40 \mu \mathrm{M})$, dopamine receptor D1 agonist R- $(+)-S K F 38393(20 \mu \mathrm{M}$, $10 \mathrm{~min})$; D1 antagonist R-(+)-SCH-23390 ( $(+)-7$-chloro-8hydroxy-3-methyl-1-phenyl-2,3,4,5-tetrahydro- $1 H$-3-benzazepine hydrochloride $(40 \mu \mathrm{M})$; D2 agonist (-)-quinpirole hydrochloride (20 $\mu \mathrm{M}, 10 \mathrm{~min}$ ); and D2 antagonist eticlopride (3-chloro5-ethyl-N-\{[(2S)-1-ethylpyrrolidin-2-yl] methyl $\}$-6-hydroxy-2methoxybenzamide $(60 \mu \mathrm{M})$, were purchased from Sigma Aldrich. Src-family kinase inhibitor, PP2 (4-amino-5-(4-chlorophenyl)7-( $t$-butyl)pyrazolo[3,4- $d]$ pyrimidine $(10 \mu \mathrm{M})$ was purchased from Calbiochem. All compounds were dissolved in artificial cerebro-spinal fluid (ACSF) on the day of the experiment.

\section{HIPPOCAMPAL AND INSULAR CORTEX SLICE PREPARATION}

After decapitation, the brain was immediately immersed in cold $\left(4^{\circ} \mathrm{C}\right)$ carboxygenated $\left(95 \% \mathrm{O}_{2}, 5 \% \mathrm{CO}_{2} ; \mathrm{ACSF}\right.$, comprising $124 \mathrm{mM} \mathrm{NaCl}, 5 \mathrm{mM} \mathrm{KCl}, 1.2 \mathrm{mM} \mathrm{MgSO}_{4}, 1.2 \mathrm{mM} \mathrm{NaH}_{2} \mathrm{PO}_{4}$,
$26 \mathrm{mM} \mathrm{NaHCO}_{3}, 10 \mathrm{mM}$ D-glucose, and $2.4 \mathrm{mM} \mathrm{CaCl}_{2}$ ), and after approximately $2 \mathrm{~min}$, both hippocampi or insular cortex were dissected out in a plate filled with cold $\left(4^{\circ} \mathrm{C}\right) \mathrm{ACSF}$ on ice. The hippocampi or insular cortex were then put on a cooled stand of a McIlwain tissue chopper TC752 (Campden Instruments Ltd, $\mathrm{UK})$, cut into $400 \mu \mathrm{m}$ slices, and then put back into a chamber filled with carboxygenated cold $\left(4^{\circ} \mathrm{C}\right)$ ACSF (Kaphzan et al., 2006, 2007).

The slices were kept in six holding chambers designed by Scientific Systems Design Company (Ontario, Canada) heated to $32^{\circ} \mathrm{C}$ and kept for $3 \mathrm{~h}$ before any pharmacological intervention. Each chamber contained four slices. Within each experiment, two chambers were used as a positive control for the quality of the slices. The remaining four chambers were the experiment chambers. $10 \mathrm{~min}$. after the pharmacological manipulation, slices were removed from the pharmacological chamber and snap-frozen on dry ice. After freezing, the slices were homogenized in $200 \mu \mathrm{l}$ of SDS sample buffer, comprising: $1 \mathrm{ml}$ glycerol, $2 \mathrm{ml}$ of $10 \%$ SDS, $1.2 \mathrm{ml}$ of $0.5 \%$ Tris- $\mathrm{HCl}(\mathrm{pH} 6.8), 4.8 \mathrm{ml}$ of DDW, and $0.5 \mathrm{ml}$ of $\beta$-mercaptoethanol. Each specimen comprised two hippocampal/insular cortex slices combined (i.e., 2 slices are $n=1)$.

\section{DRUG ADMINISTRATION}

SKF38393 was dissolved in saline $(0.9 \% \mathrm{NaCl})$ and administered intraperitoneally ( $5 \mathrm{mg} / \mathrm{kg}$ ) to C57BL/6 and NR2B F1472 mice. Mice were sacrificed 15 min later and tissue was collected. For incidental taste learning experiment, SCH23390 was dissolved in saline $(0.9 \%)$ and administered intraperitoneally (i.p., $0.05 \mathrm{mg} / \mathrm{kg}$ ) to $\mathrm{C} 57 \mathrm{BL} / 6$ mice $30 \mathrm{~min}$ prior to the novel taste exposure.

\section{BIOCHEMISTRY}

\section{Collection of tissue samples}

Fifteen minutes following SKF38393 injection (5 mg/kg, i.p.) or $20 \mathrm{~min}$ following novel taste exposure, animals were decapitated and the hippocampus and insular cortex were collected and frozen in liquid nitrogen and stored in $-80^{\circ} \mathrm{C}$. The obtained tissues were homogenized in a glass-teflon homogenizer in a lysis buffer containing $10 \mathrm{mM}$ HEPES, pH 7.4, 2 mM EDTA, $2 \mathrm{mM}$ EGTA, $0.5 \mathrm{mM}$ DTT, 1\% phosphate inhibitor mixture (Sigma), and $1 \%$ protease inhibitor mixture (Sigma). Protein quantification was made with BCA Protein Assay Kit (GE Healthcare). Appropriate volumes of 2XSDS sample buffer (10\% glycerol, 5\% $\beta$-mercaptoethanol, 4\% SDS, $120 \mathrm{mM}$ Tris- $\mathrm{HCl}, \mathrm{pH}$ 6.8) were added to the homogenates, and samples were boiled for $5 \mathrm{~min}$ and stored at $-20^{\circ} \mathrm{C}$.

\section{Western blotting}

Samples in SDS sample buffer were subjected to SDS-PAGE (7.5-10\%) and Western blot analysis. Lanes were loaded with equal amount of protein. Following transfer to a nitrocellulose membrane $(0.45 \mu \mathrm{m}$, Whatman), bands were visualized with Ponceau staining (Bio-Rad). Membranes were blocked in 3-5\% BSA (depending on the primary antibody) for $1 \mathrm{~h}$ at room temperature, before being incubated overnight at $4^{\circ} \mathrm{C}$ with the primary antibodies: p44/42 MAP kinase (1:1000) and (PhosphoP44/42 MAP Kinase-(Thr202/Tyr204, 1:1000, Cell Signaling); 
Src (1:500, Upstate Biotechnology); NR2B antibody (1:500), $\beta$-actin (1:3000, Santa-Cruz Biotechnology); Phospho-(Tyr1472)NR2B (1:500, Embel); and Phospho-(Tyr418)-Src (1:500, Embel).

Following three washing steps with Tris-buffered saline (140 mM NaCl, $20 \mathrm{mM}$ Tris, pH 7.6) plus 0.1\% Tween 20 (TBST), membranes were incubated for $1 \mathrm{~h}$ at room temperature with secondary HRP-linked antibodies: goat-anti-Rabbit (IgG) HRP conjugated; Goat anti-mouse (IgG) HRP conjugated; and rabbit anti-goat (IgG) HRP conjugated (1:10,000, Jackson ImmunoResearch). Immunodetection was accomplished with the Enhanced Chemiluminescence EZ ECL kit (Biological Industries). Quantification of immunoblots was performed with a CCD camera and Quantity One software (Bio-Rad). Each sample was measured relative to the background. Phosphorylation levels were calculated as the ratio of phosphorylated protein and total amount of protein.

\section{BEHAVIOR}

\section{Conditioned taste aversion}

CTA acquisition and extinction. Conditioned taste aversion was performed as described previously (Rosenblum et al., 1993; BarkiHarrington et al., 2009). Saccharin (0.5\% w/v, sodium salt) was used as the unfamiliar taste in training, i.e., the conditioned stimulus (CS), and i.p. injection of $\mathrm{LiCl}$ ( $2 \%$ of the body weight) as the malaise-inducing agent, i.e., unconditioned stimulus (US). The mice were trained for 3 days to drink water once a day during a 20-min period from two pipettes, each containing $5 \mathrm{ml}$ of water. On the conditioning (i.e., fourth) day, they were allowed to drink the saccharin solution containing $0.5 \%$ sodium saccharin, instead of water, from similar pipettes during a 20 -min period, and $40 \mathrm{~min}$ later they were injected with $0.14 \mathrm{M} \mathrm{LiCl}$ solution at $2 \%$ body weight. Two days after conditioning, the mice were tested in a multiple-choice test involving two pipettes with water and two with saccharin. The behavioral data are presented in terms of an aversion index, expressed as $[\mathrm{ml}$ water/ $(\mathrm{ml}$ water $+\mathrm{ml} \mathrm{sac}$ charin) $] \times 100$ consumed in the test. The greater the preference for water over the novel taste, the higher the aversion index and, therefore, better memory.

\section{Incidental taste learning}

Mice were separated into individual housing cages and underwent 3-day water-restriction training, in which they were offered $10 \mathrm{ml}$ of water from two pipettes, each containing $5 \mathrm{ml}$ once a day for $20 \mathrm{~min}$. During days 4-8, the mice were given a multiple-choice test comprising two pipettes with water and two with saccharin, during a 20-min period (Rosenblum et al., 1993). The behavioral data are presented in terms of aversion index, defined as $[\mathrm{ml}$ water $/(\mathrm{ml}$ water $+\mathrm{ml}$ saccharin $)]$ consumed in the test.

\section{STATISTICS}

Results are expressed as means \pm SEM. All data complied with the normality distribution, determined by the Shapiro-Wilk test. The significance of differences was evaluated using one-way ANOVA followed by Tukey's post-hoc test. For behavioral studies Student's $t$-test, repeated-measures ANOVA and two-way ANOVA were performed. Significant levels were noted as follows: ${ }^{*} p<0.05$, ** $p<0.01,{ }^{* * *} p<0.001$.

\section{RESULTS \\ DOPAMINE D1 BUT NOT D2 RECEPTORS ACTIVATE ERK1/2 IN THE MATURE HIPPOCAMPUS AND CORTEX}

We have previously shown that dopamine and NMDA converge to activate ERK1/2 and that this convergence is dependent on the NMDA receptor itself (Kaphzan et al., 2006, 2007). In the present study, we determined which dopamine receptor is involved in this interaction in the mature hippocampus and cortex. Acute rat hippocampal slices were incubated with $20 \mu \mathrm{M}$ dopamine. As expected, dopamine induced ERK1/2 activation $(1.26 \pm 0.03, p<0.001, n=24$; Figure S1A) and blocking both the D1 receptor $(\mathrm{SCH} 23390,40 \mu \mathrm{M})$ and the D2 receptor (eticlopride, $60 \mu \mathrm{M}$ ) inhibited its activation (dopamine+etic+SCH: $0.81 \pm 0.03, p<0.01$ vs. dopamine, $p<0.05$ vs. control, $n=6$; Figure $\mathrm{S} 1 \mathrm{~B})$. In order to determine which receptor is responsible for ERK1/2 activation, we applied dopamine D1 agonist SKF38393 $(20 \mu \mathrm{M}, 10 \mathrm{~min})$ with or without its antagonist SCH23390 (40 $\mu \mathrm{M})$. In both brain areas, SKF38393 increased ERK activity (hippocampus: $1.22 \pm 0.03, p<0.01, n=8$ and insular cortex: $1.30 \pm 0.05, p<0.01, n=8$; Figures S1C,E), and coapplication with SCH23390 inhibited this activation in both brain areas (hippocampus: $1.05 \pm 0.03, p<0.01$ vs. SKF38393, $n=8$, and insular cortex: $1.12 \pm 0.06, p<0.01$ vs. SKF38393, $n=8$; Figures S1C,E). However, application of the D2 agonist quinpirole $(20 \mu \mathrm{M}, 10 \mathrm{~min})$ did not produce any effect on ERK1/2 in either the hippocampus $(1 \pm 0.04, p=0.09, n=8$; Figure $\mathrm{S} 1 \mathrm{C})$ or insular cortex $(1.04 \pm 0.06, p=0.515)$. Moreover, co-application of the D2 agonist quinpirole with D1 antagonist SCH23390 did not result in ERK1/2 activation in either the hippocampus (Figure S1D) or insular cortex (Figure S1F). These results suggest that D1 but not D2 receptors activate ERK1/2 in the mature hippocampus and insular cortex.

\section{ACTIVATION OF ERK1/2 BUT NOT NR2B Y1472 BY DOPAMINE IS NMDA RECEPTOR-DEPENDENT}

Similarly to Kaphzan et al. (2006), we show that co-application of dopamine with the NMDA receptor antagonist APV $(D(-)$-APV (D-2-amino-5-phosphonovaleric acid, $40 \mu \mathrm{M}$ ) inhibited ERK1/2 activation in hippocampal slices (dop+APV: $1.07 \pm 0.04, p<0.01$ vs. dop, $p<0.01$ dop vs. control, $n=6$; Figure 1A). These results indicate that indeed the convergence of the dopaminergic and glutamatergic inputs converge on the NMDA receptor. Following the results above (Figure 1A), we investigated whether the convergence of the dopamine and glutamate signals on the NMDA receptor is mediated via the phosphorylation of the NR2B Y1472 residue. Indeed, dopamine application increased NR2B Y1472 phosphorylation compared to control in hippocampal slices $(1.47 \pm 0.12, p<0.01, n=24$; Figure 1B). We next examined whether this NR2B Y1472 phosphorylation was NMDA receptor-dependent. Interestingly, blocking the NMDA receptor with $40 \mu \mathrm{M}$ APV did not affect NR2B Y1472 phosphorylation induced by dopamine (dop+APV: $1.56 \pm 0.2, p=0.92$ vs. dop, $n=12$; Figure 1C), indicating that NR2B Y1472 phosphorylation is NMDA receptor independent. 
A
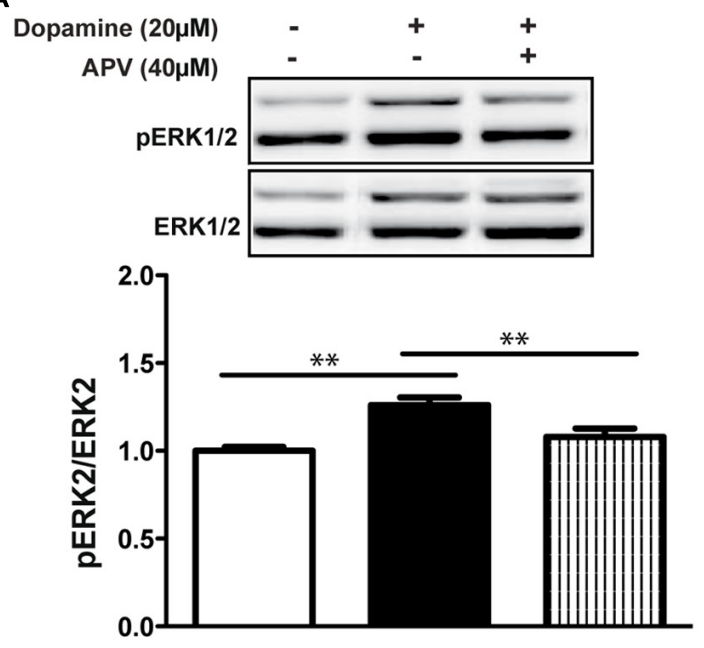

C
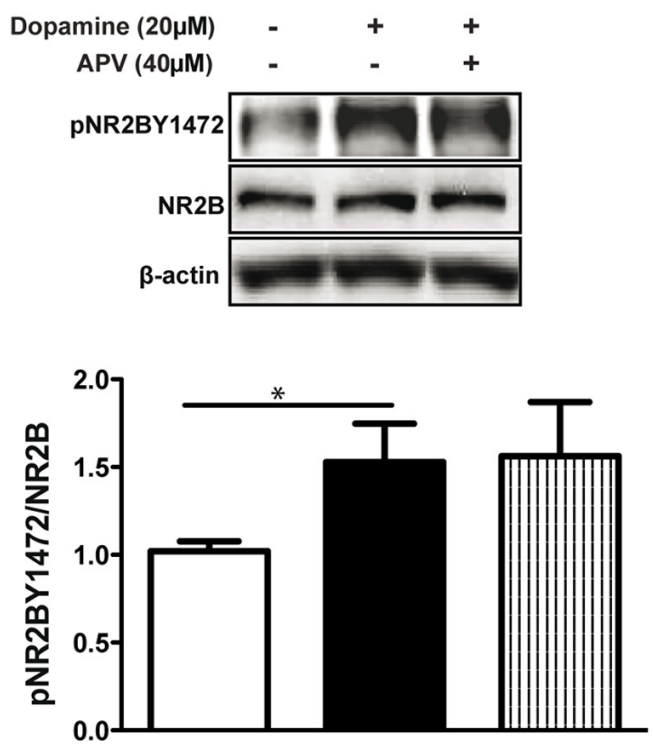

FIGURE 1 |Activation of ERK1/2 but not NR2B Y1472 by dopamine is NMDA receptor-dependent. (A) Dopamine $(20 \mu \mathrm{M}, 10 \mathrm{~min})$ increases phosphorylation of ERK $1 / 2$ in rat hippocampal slices. NMDA receptor antagonist APV $(40 \mu \mathrm{M})$ abolishes this effect $\left({ }^{*} p<0.01\right.$ $n=6)$. (B) Dopamine $(20 \mu \mathrm{M}, 10 \mathrm{~min})$ increases NR2B Y1472

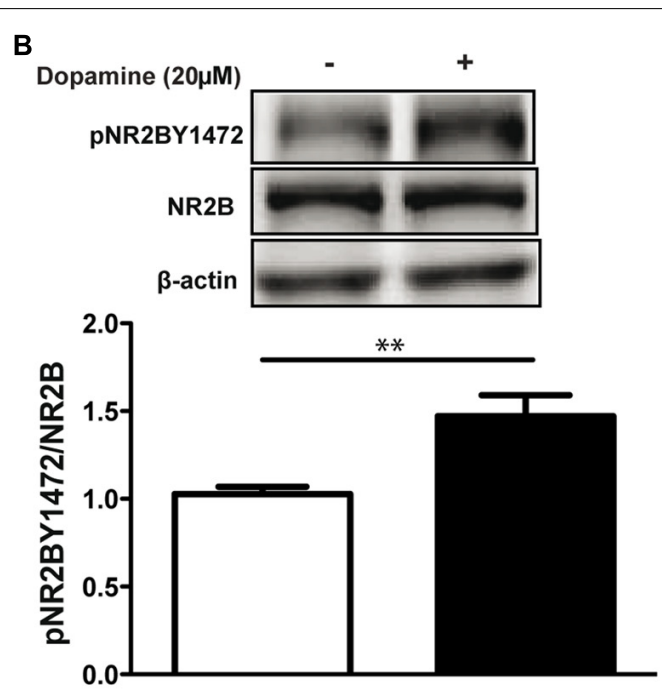

D
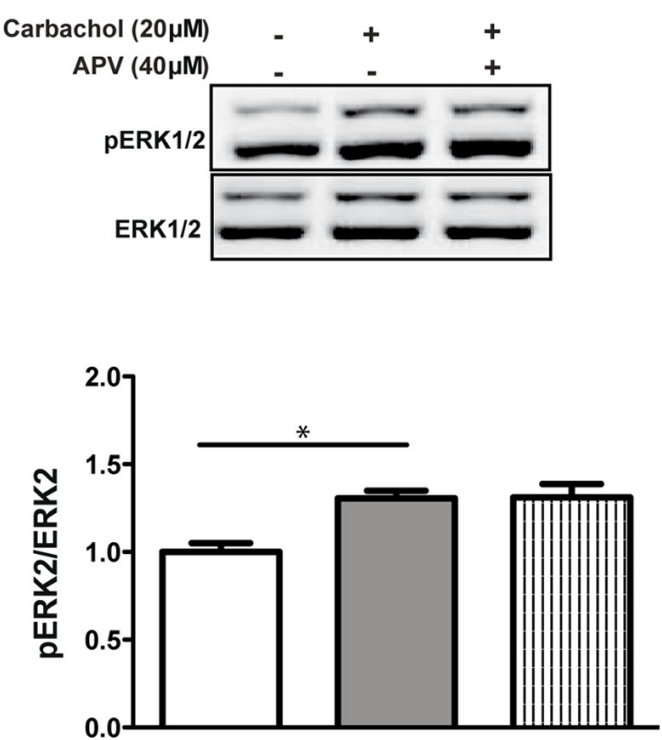

\section{DOPAMINE BUT NOT ACETYLCHOLINE ACTIVATES ERK1/2 SPECIFICALLY VIA THE NMDA RECEPTOR}

As known from previous studies, other neuromodulators such as acetylcholine can increase ERK1/2 activation in various brain areas (Rosenblum et al., 2000). In order to test if ERK1/2 activation via the NMDA receptor is $\mathrm{mAChR}$ dependent, we treated slices with the agonist of the muscarinic receptors, carbachol (Cch, $20 \mu \mathrm{M}$ ). Similarly to dopamine, carbachol leads to ERK1/2 activation $(1.30 \pm 0.02, p<0.05, n=12$; Figure 1D).
However, application of APV did not inhibit Cch-dependent ERK1/2 (Cch+APV: $1.31 \pm 0.04, p=0.96$ vs. Cch, $n=12$; Figure 1D). These results suggest segregation between dopamine and acetylcholine effects in the mature brain.

\section{DOPAMINE D1 BUT NOT D2 RECEPTOR INDUCES NR2B Y1472 PHOSPHORYLATION IN THE HIPPOCAMPUS AND INSULAR CORTEX}

Following our observation that dopamine induces ERK1/2 activation and NR2B Y1472 phosphorylation, we tested whether NR2B 
Y1472 phosphorylation was also D1 receptor-selective. We treated hippocampal and insular cortex slices with D1 or D2 agonists separately or concomitantly with their antagonists. Immunoblot analysis showed that indeed the D1 but not D2 receptor agonists mediate NR2B Y1472 phosphorylation in both hippocampus and insular cortex (hippocampus: $1.20 \pm 0.05, p<0.05, n=9$, insular cortex: $1.28 \pm 0.06, p<0.05, n=9$; Figures S2A,C), and that co-application of SKF38393 with the D1 receptor antagonist SCH23390 abolished this effect (hippocampus: $1.05 \pm 0.07$, $p<0.05$ vs. SKF38393, $n=9$; insular cortex: $1.04 \pm 0.09$, $p<0.05$ vs. SKF38393; Figures S2A,C). Similarly to the results with ERK1/2 (Figure S1), the D2 agonist quinpirole had no effect on NR2B Y1472 phosphorylation in these areas. Moreover, coapplication of the D1 antagonist SCH23390 had no effect on NR2B Y1472 phosphorylation (Figures S2B,D). These results demonstrate that dopamine D1 receptor induces both ERK1/2 activation and NR2B Y1472 phosphorylation in mature hippocampus and insular cortex.

\section{ERK1/2 AND NR2B Y1472 PHOSPHORYLATION IS SrC FAMILY KINASE-DEPENDENT}

Src family kinases (SFKs) modulate the NMDA receptor function and are important for different aspects of the receptor properties including for trafficking, mainly through phosphorylation of the NR2B subunit at Y1472 (Dunah and Standaert, 2001; Dunah et al., 2004). We therefore examined the role of SFKs in NMDA receptordependent ERK1/2 activation induced by dopamine. Dopamine induced SFK phosphorylation of ERK1/2 at Y418 (1.22 \pm 0.04 , $p<0.05, n=10)$ while the SFK inhibitor PP2 $(10 \mu \mathrm{M})$ blocked phosphorylation on Y418 (0.96 $\pm 0.06, p<0.05$ vs. dop, $n=16$; Figure 2A). Moreover, dopamine increased phosphorylation of ERK1/2 $(1.31 \pm 0.05, p<0.01, n=10)$ and NR2B Y1472 $(1.26 \pm 0.08, p<0.05, n=16$; Figures 2B,C). Inhibition of the SFKs with PP2 blocked dopamine-dependent tyrosine phosphorylation of NR2B Y1472 (dop+PP2: $1.09 \pm 0.07, p<0.05$ vs. dop, $n=16$; Figure 2C) and, more importantly, inhibited ERK1/2increased activation at the same time (dop+PP2: $1.11 \pm 0.05$, $p<0.05$ vs. dop, $n=16$; Figures 2B,C). In addition, we observed correlations between ERK1/2 activation and phosphorylation of NR2B Y1472 ( $r=0.41$; Figure 2E), and between SFK activation and NR2B Y1472 phosphorylation $(r=0.58, p<0.05$; Figure 2D).

\section{DOPAMINE-DEPENDENT NR2B Y1472 PHOSPHORYLATION IS ESSENTIAL FOR ERK1/2 ACTIVATION}

In order to test the general significance of these results to other species and to use transgenic mice to demonstrate causality, we repeated the experiment described above in C57BL/6 wild-type mice. As we had seen in the rat, dopamine increased activation of the SFKs in the hippocampus of mice $(1.24 \pm 0.06, p<0.001$, $n=6$; Figure 3A) and increased phosphorylation of ERK1/2 $(1.28 \pm 0.04, p<0.05, n=6$; Figure 3B) and NR2B Y1472 (1.56 $\pm 0.21, p<0.05, n=6$; Figure 3C). Co-application with the inhibitor PP2 blocked the activation of SFKs (dop+PP2: $0.44 \pm 0.05, p<0.001$ vs. dop, $n=10$; Figure 3A) and phosphorylation of ERK1/2 (dop+PP2: $0.95 \pm 0.06, p<0.05$ vs. dop, $n=10$ ) and NR2B Y1472 (dop+PP2: $0.98 \pm 0.2, p<0.05$ vs. dop, $n=10$; Figures 3B,C). These data suggest that dopamine induces ERK1/2 activation via NR2B Y1472 phosphorylation by the SFKs in mice as in rats.

In light of the above results, we hypothesized that NR2B Y1472 phosphorylation may be upstream and essential for ERK1/2 activation by dopamine. In order to test this hypothesis, we tested hippocampal slices from non-phosphorylatable NR2B F1472 mutant mice and their wild-type littermates (Nakazawa et al., 2006). Twoway ANOVA followed by post hoc analysis showed that dopamine induced ERK activation in the wild-type but not NR2B F1472 mice (wild-type: $1.20 \pm 0.04, F=4.90, p<0.05$; Figure 3D). There was a significant effect of the genotype $(F=6.01 ; p<0.05)$. Moreover, there was a significant interaction between treatment $\times$ genotype $(F=5.13, p<0.05$; Figure $3 D)$. Similar results were found with the D1 receptor agonist SKF38393 which activated ERK1/2 in wild-type mice (wild-type: $1.20 \pm 0.03, F=3.94$, $p<0.05$; Figure 3E). There was a significant effect of the genotype $(F=5.28 ; p<0.05)$ and also interaction between treatment $\times$ genotype $(F=5.28, p<0.05$; Figure $3 \mathrm{E})$. Following our results above that muscarinic receptor-dependent ERK1/2 activation is NMDA receptor independent (i.e., using APV; Figure 1D), we hypothesized that carbachol will induce ERK1/2 activation in both wild-type and NR2B F1472 hippocampal slices. Indeed, application of Cch induced ERK1/2 activation in the NR2B F1472 mutant mice similar to that in the wild-type ones $(1.20 \pm 0.02, p<0.01, n=12$; Figure $3 \mathbf{F})$. These results indicate the pathway connecting specifically dopamine, NR2B Y1472 phosphorylation, and ERK1/2 activation in the mature brain.

\section{BOTH NOVEL TASTE- AND DOPAMINE D1 AGONIST-INDUCED ERK1/2 ACTIVATION ARE NR2B Y1472-DEPENDENT}

In order to evaluate the physiological effect of the pathway described above in vivo and its impact on cortical-dependent novelty learning NR2B F1472 mutant mice and wild-type littermates were injected with either saline or low concentration of SKF38393 (5 mg/kg) and both hippocampus and insular cortex tissues were collected 15 min post-injection. Western blotting analysis showed that indeed in vivo as in vitro, D1 receptor stimulation induces NR2B Y1472 phosphorylation in wild-type hippocampus (1.25 $\pm 0.10, p<0.05, n=6$; Figure 4B) and insular cortex $(1.56 \pm 0.09, p<0.01, n=6$; Figure 4D). However, two-way ANOVA followed by post hoc analysis showed that ERK1/2 activation following the D1 agonist treatment was detected in the wild-type mice but not in the NR2B F1472 mice in both brain areas (hippocampus: $1.22 \pm 0.05, F=3.98, p<0.05$; insular cortex: $1.49 \pm 0.09, F=6.34, p<0.05$; Figure 4A). There was also a significant effect of the genotype $(F=6.91, p<0.05)$ and interaction of treatment $\times$ genotype in the hippocampus $(F=3.92, p<0.05)$; Figure 4A) and in the insular cortex $(F=5.72, p<0.05)$ for the genotype $(F=5.72, p<0.05$; Figure 4C). These results demonstrate the necessary role of NR2B Y1472 phosphorylation in ERK1/2 activation by dopamine in the mature brain.

In light of the in vitro and in vivo pharmacological results, we set to examine whether the dopamine-induced NR2B Y1472 phosphorylation was important for consolidation of novel sensory 
A
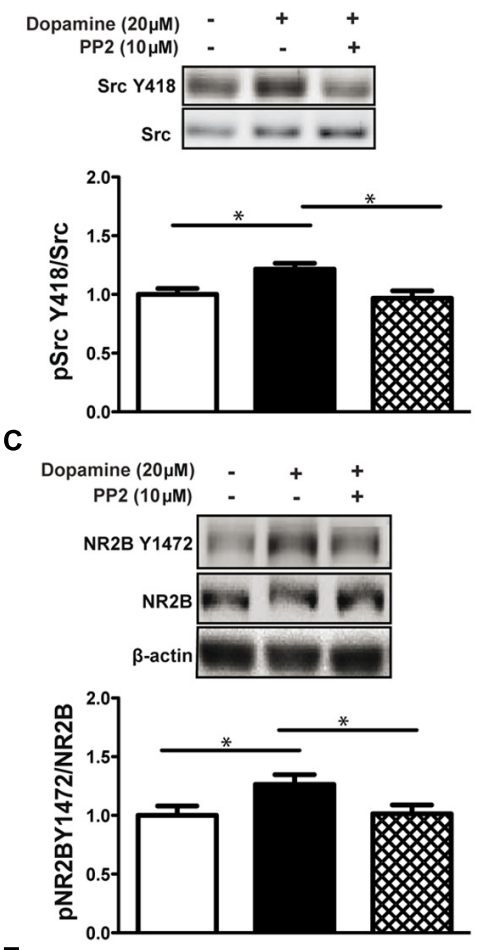

E

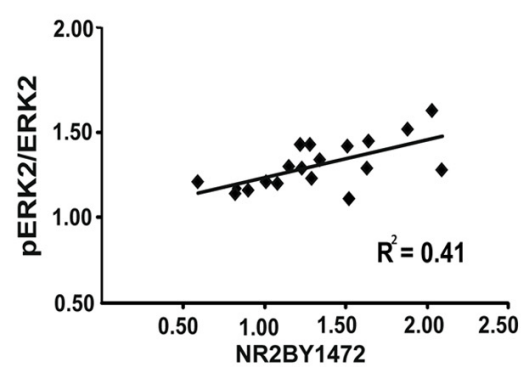

B

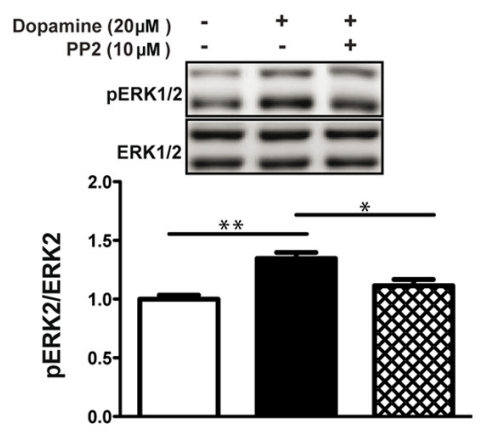

D

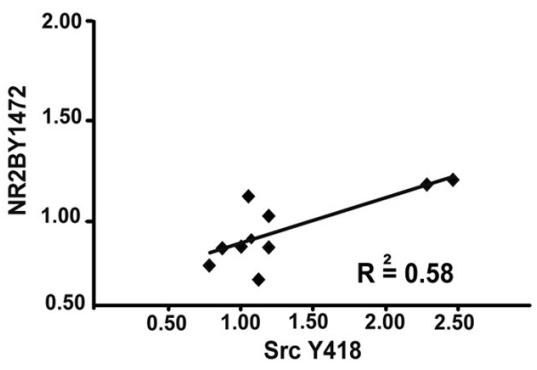

FIGURE 2 | ERK1/2 and NR2B Y1472 phosphorylation by dopamine is Src family kinase-dependent. (A) Dopamine $(20 \mu \mathrm{M}, 10 \mathrm{~min})$ increases Tyr-418-Src family kinases (pSFKs) phosphorylation in rat hippocampal slices $\left({ }^{*} p<0.05\right)$, and the SFK inhibitor, PP2 $(10 \mu \mathrm{M})$, blocks this effect $\left({ }^{*} p<0.05\right.$ vs. dopamine, $n=16$ ). (B) Dopamine induces phosphorylation of ERK $1 / 2$ $\left({ }^{*} p<0.01\right)$. This induction is blocked by PP2 $\left(n=16,{ }^{*} p<0.05 \mathrm{vs}\right.$. dopamine). (C) PP2 blocks the dopamine-induced NR2B Y1472 phosphorylation ( $n=16,{ }^{*} p<0.05$ vs. control and ${ }^{*} p<0.05$ vs. dopamine). (D) Positive correlation between NR2B Y1472 and Src Y418 phosphorylation following dopamine ( $r$ Pearson $=0.58,{ }^{*} p<0.05$ ). (E) Dopamine-induced Y1472 NR2B phosphorylation is correlated with the pERK levels ( $r$ Pearson $=$ $\left.0.41,{ }^{*} p<0.05\right)$. Data are means \pm SEM. information. It is known that novel taste learning induces both ERK1/2 and NR2B Y1472 phosphorylation in the gustatory cortex which resides within the insular cortex (Belelovsky et al., 2005; Barki-Harrington et al., 2009). Therefore, we hypothesized that impairment of dopamine-dependent ERK1/2 activation in the NR2B F1472 mutant mice would lead to a behavioral deficit in learning of cortical-dependent novel taste information. Wild-type and NR2B F1472 mutant mice were exposed to novel taste (saccharin) and were sacrificed 20 min later for biochemical analysis. Two-way ANOVA followed by post hoc analysis revealed that similarly to the D1 agonist, novel taste increased ERK1/2 activation in the wild-type mice, while no ERK1/2 activation was found in the NR2B F1472 mice (wild-type: $1.20 \pm 0.04, F=3.82, p<0.05$; Figure 4E). There was also significant effect of the genotype
$(F=9.51, p<0.01)$ and interaction of treatment $\times$ genotype $(F=8.30, p<0.01)$. In addition and as was reported before, novel taste induced NR2B Y1472 phosphorylation in the wild-type but not in the NR2B F1472 mice (data not shown). Moreover, novel taste memory is dopamine D1 receptor dependent as was shown previously (Berman et al., 2000; Cannon et al., 2005), since blocking the D1 receptor with SCH23390 (0.05 mg/kg, i.p.) $30 \mathrm{~min}$ prior to the novel taste exposure impaired the memory of the taste in the first choice test day in wild-type mice $33 \pm 0.03 \%$ for salineinjected mice vs. $16 \pm 0.08 \%$ for SCH-injected mice, $p<0.05$, $n=9$ ). There was significant effect of the testing days, indicating normal attenuation of neophobia (Figure $\mathbf{4 F}$ ). There were no differences in the total drinking volume during the test days (Table S1). 

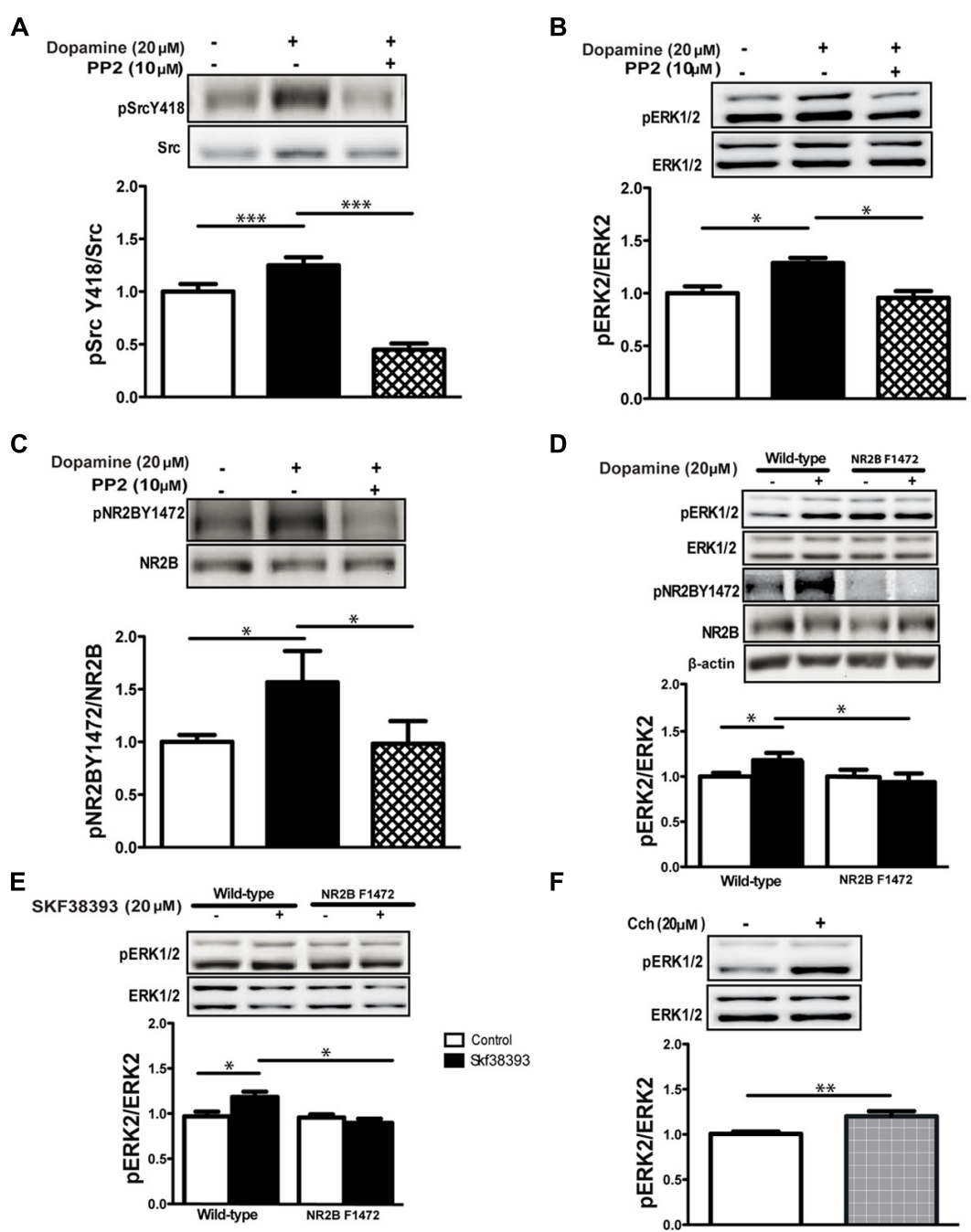

FIGURE 3 | Dopamine-induced NR2B Y1472 phosphorylation by SFKs is necessary for ERK activation. (A) Dopamine $(20 \mu \mathrm{M}, 10 \mathrm{~min})$ increases phosphorylation levels of Src Y418 (*** $p<0.001$ vs. control, $n=6)$ (B) pERK1/2 (* $p<0.05$ vs. control, $n=6)$, (C) NR2B Y1472 (*p<0.05 vs. control, $n=6)$ in C57BL/6 mice hippocampal slices. PP2 $(10 \mu \mathrm{M})$ prevents these dopamine-induced increases in phosphorylation levels ( $n=10)$. (D) Dopamine-induced elevation of phosphorylation of ERK1/2 is abolished in hippocampal slices from NR2B F1472 ( ${ }^{*} p<0.05$ vs. control for wild-type mice, $n=6$ ). (E) SKF38393 application (20 $\mu \mathrm{M}, 10 \mathrm{~min}$ ) increases the phosphorylation of ERK1/2 in the wild-type mice hippocampal slices but not in the NR2B F1472 mice $\left(^{*} p<0.05\right.$ for wild-type, $n=6$ ). (F) Carbachol (Cch; $20 \mu \mathrm{M}, 10 \mathrm{~min}$ ) application increases the phosphorylation of ERK1/2 in NR2B F1472 slices $\left({ }^{*} p<0.01, n=12\right)$. Data are means \pm SEM.

\section{NR2B Y1472 PHOSPHORYLATION IS ESSENTIAL FOR NOVEL TASTE LEARNING}

The results above suggested that dopamine plays a key role in novel taste memory. We thus hypothesized that impairment of dopamine-dependent ERK1/2 activation in the NR2B F1472 mutant mice would lead to a behavioral deficit in learning of novel taste information. C57BL/6 wild-type and NR2B F1472 mutant mice were subjected to two cortical-dependent learning tasks: attenuation of neophobia of novel taste learning and CTA. NR2B F1472 mutant mice showed lower preference to the novel taste saccharin than the wild-type mice at the first test day $(26 \pm 0.04 \%$ for wild-type mice vs. $17 \pm 0.03 \%$ for NR2B F1472 mice, $n=16)$ and second test day ( $28 \pm 0.03 \%$ for the wild-type mice vs. $19 \pm 0.03 \%$ for NR2B F1472 mice, $n=16$; Figure 5A).
Repeated-measures ANOVA showed that there was a significant difference between the groups $(F=641, p<0.001)$ and also a significant effect of the test days $(F=6.34, p<0.05$; Figure 5A). There were no differences in total volume drinking during the test days (Table S2). Associative memory was normal in the NR2B F1472 mice (Figure 5B). The NR2B F1472 mice showed high aversion index at the first test day similar to the wild-type littermates $(84.25 \pm 0.11$ for wild-type mice and $80.21 \pm 0.06$ for the NR2B F1472 mice, $n=9, p=0.45)$. Repeated-measures ANOVA showed a significant effect of the testing days $(F=3.51, p<0.05$; Figure 5B) indicating normal extinction for both groups. There were no differences in the total drinking volume during the test days (Table S3). These results imply of the importance of the NR2B Y1472 in learning of novel taste information. 

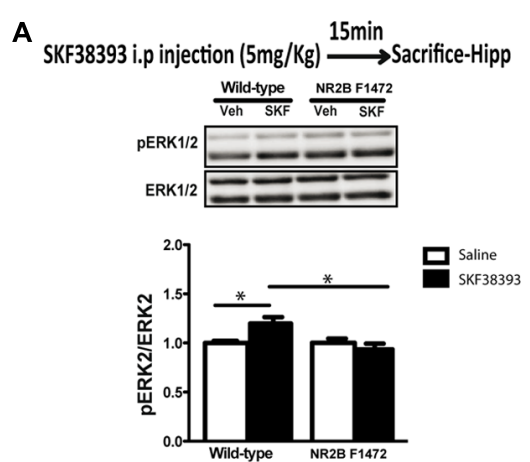

C
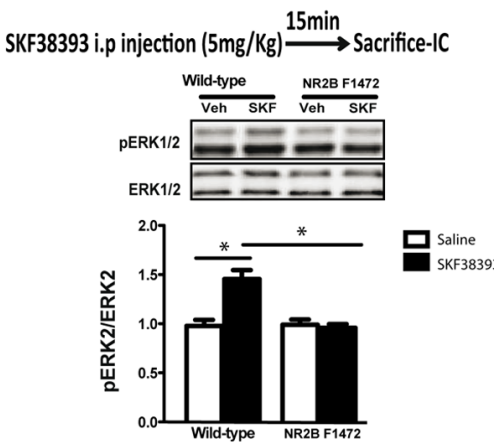

E

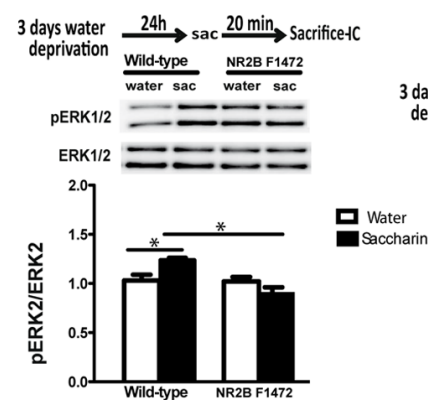

FIGURE 4 | Dopamine D1 receptor induces ERK1/2 and NR2B Y1472 phosphorylation in vivo in both hippocampus and insular cortex. (A) Injection of SKF38393 (5 mg/kg, i.p.) increases pERK1/2 levels in wild-type mice hippocampus, but not in NR2B F1472 mice $\left(^{*} p<0.05\right.$ vs. control and ${ }^{*} p<0.05$ vs. wild-type SKF38393, $n=5$ ). (B) Injection of SKF38393 increases NR2B Y1472 phosphorylation levels in the wild-type mice hippocampus ( ${ }^{*} p<0.05$ vs. control), but not in NR2B F1472 mice $(n=6)$. (C) SKF38393 (5 mg/kg, i.p.) increases pERK1/2 and (D) pNR2B Y1472 levels

\section{DISCUSSION}

Our study describes a molecular pathway of dopamine and glutamate signaling converging on the NMDA receptor itself, which results in ERK1/2 activation in the mature hippocampus and cortex. Dopamine D1 receptor but not D2 induces ERK1/2 activation in an NMDA receptor-dependent manner. Specifically, D1 receptor activation leads via the SFKs to phosphorylation of NR2B at residue Y1472, which in turn, activates ERK1/2. Furthermore, we have found a correlation between NR2B Y1472 phosphorylation and ERK1/2 activation in the mature brain. Using NR2B F1472 mutant mice, we have demonstrated in vitro and in vivo the necessity of the NR2B Y1472 for ERK1/2 activation following D1 receptor activation and for novel taste learning.

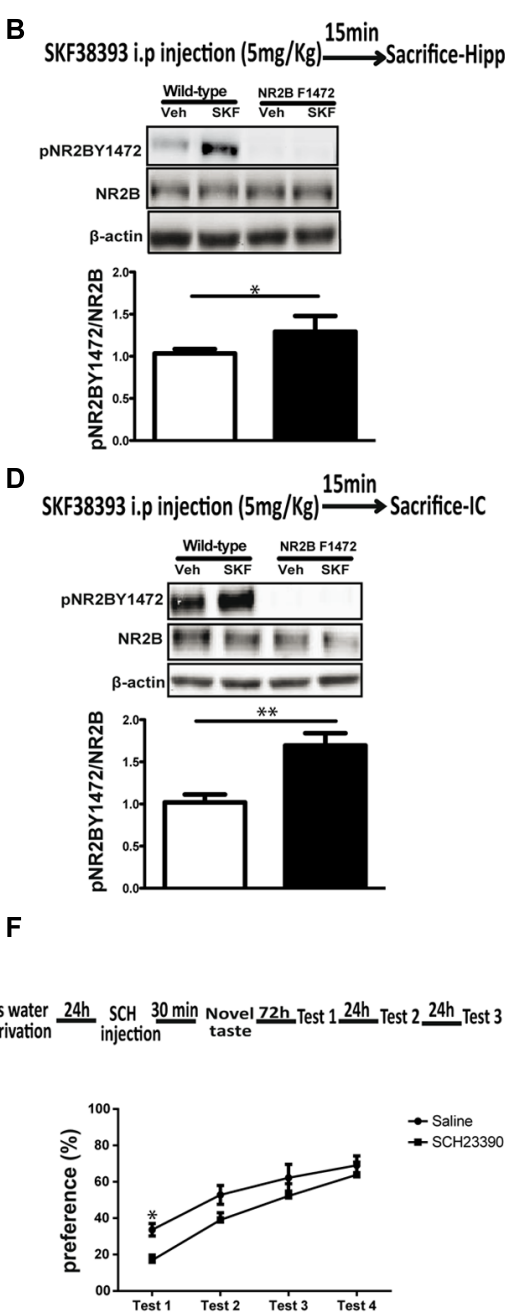

in the insular cortex wild-type mice but not in the NR2B F1472 (pERK1/2: ${ }^{*} p<0.05$ vs. control and ${ }^{*} p<0.05$ vs. wild-type SKF38393, $n=5$; pNR2B Y1472L: ${ }^{*} p<0.01$ vs. control, $n=6$ ). (E) Novel taste exposure for $20 \mathrm{~min}$ induces the phosphorylation of ERK1/2 in wild-type mice but not in NR2B F1472 mice ( ${ }^{*} p<0.05$ vs. water and ${ }^{*} p<0.05$ vs. wild-type saccharin, $n=10)$. (F) Injection of D1 receptor antagonist SCH23390 $(0.05 \mathrm{mg} / \mathrm{kg}$, i.p.) prior to novel taste exposure impairs taste memory $72 \mathrm{~h}$ after in the first retrieval day $\left({ }^{*} p \leq 0.05, n=9\right)$. Data are means \pm SEM. 


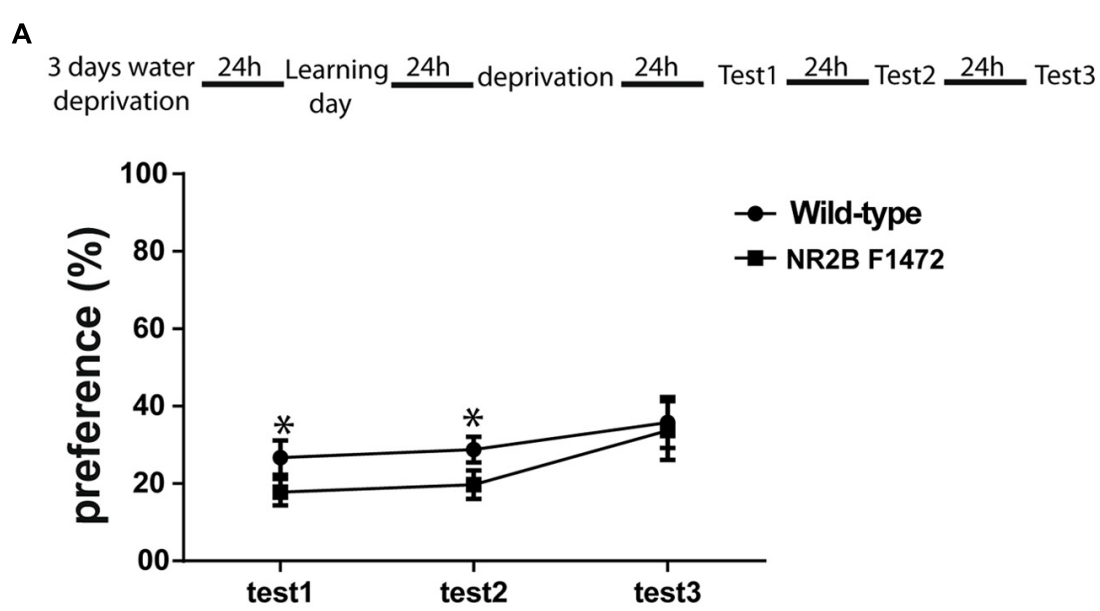

B
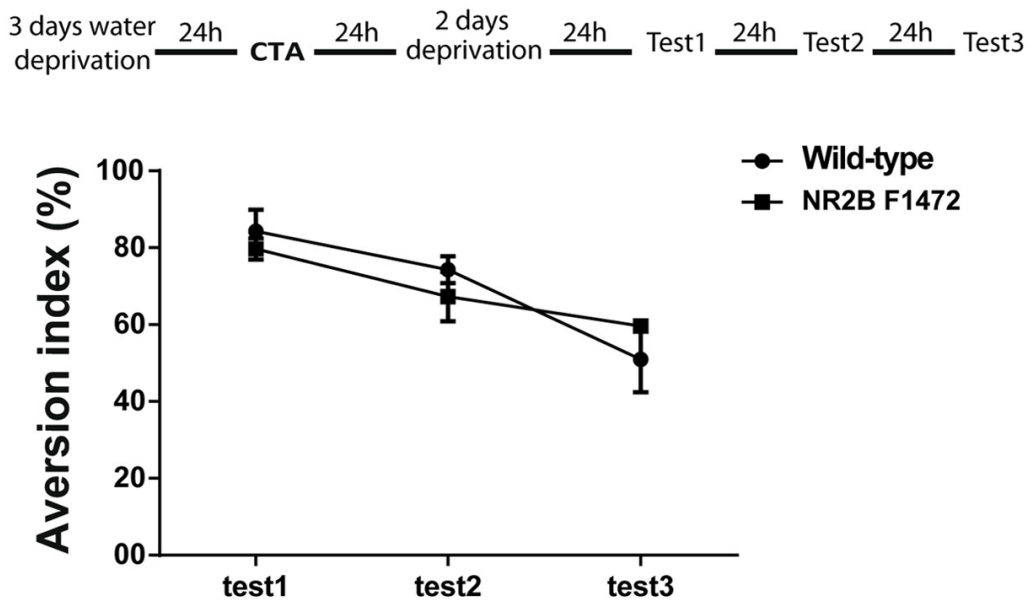

FIGURE 5 | NR2B Y1472 phosphorylation is necessary for novel taste learning. (A) NR2B F1472 mice prefer significantly less novel taste on the first and second choice tests $\left({ }^{*} p<0.05\right)$. However, attenuation of neophobia is normal as can be seen by the slope (wild-type $n=8$, NR2B F1472 $n=9$ ). (B) Conditioned taste aversion memory was normal in the NR2B F1472 mice compared to their wild-type $(n=9)$. Data are means \pm SEM.
Carli, 2011), novel information (Coccurello et al., 2012), and longterm memory of taste learning (Guzman-Ramos and BermudezRattoni, 2011) as well as addiction (Zhang et al., 2004; Jenab et al., 2005). Stimulation of both dopamine D1 and NMDA receptors in the striatum also activates ERK1/2 (Valjent et al., 2005). In accordance with these findings, we report here that dopamine D1 and NMDA receptors are also required for ERK1/2 activation in both mature hippocampus and cortex, and that dopamine-dependent ERK1/2 activation is NMDA receptor-dependent, since blocking the NMDA receptor with APV prevented the dopamine-dependent ERK $1 / 2$ activation.

In spite of the abovementioned evidence for dopamine-NMDA receptor interplay, little is known about the mechanism underlying this interaction. Previous studies have suggested different mechanisms for dopamine-NMDA interactions, whether via direct protein-protein interactions or via G protein-dependent/independent regulation of the NMDA receptor (Lee et al., 2002; Lee and Liu, 2004; Martina and Bergeron, 2008). In this study, we report that dopamine D1 receptor but not D2 induces the phosphorylation of the NR2B subunit at the Y1472 residue both in the hippocampus (shown ex vivo) and the insular cortex (shown in vivo). This mechanism was found also in other brain areas. For example, in striatal and pre-frontal cortex neurons, activation of the D1 receptors increases tyrosine phosphorylation of NR2A and NR2B, and produces rapid alteration in the distribution of the NR1, NR2A, and NR2B subunits of the NMDA receptor, with accumulation of these proteins in synaptosomal membranes (Dunah and Standaert, 2001). Furthermore, activation of dopamine D1 receptor leads to trafficking of the NMDA receptor in the striatum in a Fyn protein tyrosine kinase-dependent manner (Dunah et al., 2004; Hallett et al., 2006), and recently it was shown in the striatum that cocaine can induce NR2B Y1472 phosphorylation via the D1 receptor (Pascoli et al., 2011). However, our data show that the dopamine-induced NR2B Y1472 phosphorylation was not NMDA receptor-dependent, suggesting a metabotropic function of the NMDA receptor as was shown to 
be important for long-term depression (Kessels et al., 2013; Nabavi et al., 2013).

NMDA receptor-dependent induction of ERK1/2 signaling is important for NMDA receptor-dependent LTP/LTD in the CA1 region of the hippocampus (Kanterewicz et al., 2000; Thiels et al., 2002) and for transcription of early genes in cortical neurons and the hippocampus (Xia et al., 1996; Chung et al., 2000). The NR2A and NR2B subunits can differentially modulate ERK1/2 activation: NR2A promotes surface expression of GluR1 and NR2B inhibits its expression via inhibition of ERK1/2 signaling (Kim et al., 2005).

Because our results show that dopamine leads to phosphorylation of the NMDA receptor at NR2B Y1472 in both rats and mice, we further examined whether NR2B Y1472 phosphorylation is necessary for ERK1/2 activation. Using NR2B F1472 mice which do not have NR2B Y1472 phosphorylation, we have shown that neither application of dopamine nor the D1 agonist SKF38393 to hippocampal slices, nor i.p. injection of dopamine results in ERK1/2 activation in the hippocampus and cortex of these mice, unlike their wild-type littermates. These results provide evidence for the importance of the convergence of the dopamine and glutamate input on the NMDA receptor in order to activate ERK1/2.

According to our data, blocking the SFKs reduced NR2B Y1472 phosphorylation following dopamine application. More importantly, blocking the SFKs inhibited ERK1/2 activation in both rats and mice, suggesting that normal function of SFKs is necessary for ERK1/2 activation in the mature hippocampus and cortex, as seen before in the striatum (Pascoli et al., 2011). This is in line with a previous study, which showed that dopamine-induced PKA and SFK activation as well as NR2B-containing NMDA receptors are crucial for LTP enhancement (Stramiello and Wagner, 2008).

There are many reports in the literature regarding the necessity of dopaminergic receptors and the NMDA receptor to process information concerning novel stimuli involving different brain regions. For example, a recent study showed that dopamine D1 receptor and NMDA receptor interactions were required for ERK1/2 activation following exposure to a novel environment (Sarantis et al., 2011). In addition, previous studies have shown that novel stimuli increase dopamine release in the hippocampus and prefrontal cortex (Ljungberg et al., 1992; Ihalainen et al., 1999; Li et al., 2003), and that novelty-seeking behavior is reduced following elimination of dopamine transmission, especially in the nucleus accumbens (Hooks and Kalivas, 1995). Exposure of rats to novel environments promoted LTP in a dopamine D1/D5-dependent manner (Li et al., 2003). The NMDA receptor NR2B subunit was shown to be important in various learning and memory tasks, such as fear conditioning (Nakazawa et al., 2006; Sotres-Bayon et al., 2007; Walker and Davis, 2008; Zhang et al., 2008), conditioned-taste learning, and novel taste learning (Rosenblum et al., 1997; Barki-Harrington et al., 2009). Moreover, deletion of the NR2B subunit from adult granule cells in the dentate gyrus causes a deficit in novelty exploration (Kheirbek et al., 2012).

Studies about taste learning have shown that exposure to novel taste induces NR2B Y1472 phosphorylation (Barki-Harrington et al., 2009) and induces increased pERK levels $20 \mathrm{~min}$ following exposure to saccharin as a novel taste (Belelovsky et al., 2005;
Elkobi et al., 2008). Moreover, the dopaminergic system, especially the D1/D5 receptor, is necessary for incidental taste learning and CTA. Mice lacking the D1 receptor show impaired CTA for sucrose but not salt (Cannon et al., 2005), and blocking the D1 receptor with $\mathrm{SCH} 23390$ in the insular cortex also impairs this learning (Berman et al., 2000). It was also shown that following exposure to novel taste, there is an off-line release of dopamine and glutamate in the insular cortex (Guzman-Ramos et al., 2010). Both D1 and D2 receptors play a role in the fructose-conditioning flavor preference in the amygdala and nucleus accumbens (Fenu et al., 2001; Baker et al., 2003; Bernal et al., 2008) and in glucoseconditioned flavor preference (Touzani et al., 2010). The circuit and neuronal type which express the increased pERK are not known. However, Arc/Arg3.1, whose expression is considered to be pERK-dependent, demonstrates lateralized expression following novel taste learning (Inberg et al., 2013).

Following the pharmacological results and the studies mentioned above, we hypothesized that NR2B F1472 mice would be impaired in novel taste learning compared with wild-type mice. Indeed, we found that NR2B F1472 mice were impaired in attenuation of neophobia to saccharin (novel taste learning) but not in associative learning of CTA. Although our results indicate impaired cortical-dependent learning of the NR2B F1472 mice, it was shown in previous studies that these mice are not impaired in hippocampal-dependent learning (Nakazawa et al., 2006), suggesting a different molecular mechanism for ERK1/2 activation. The importance of NR2B Y1472 phosphorylation following dopamine stimulation for the activation of ERK1/2 and learning of novel information may be due to 1) NR2B Y1472 phosphorylation results in increase of calcium influx to the cell, which leads to more ERK1/2 activation as previously shown (Pascoli et al., 2011), or 2) D1 receptors induce NR2B Y1472 phosphorylation, and increase synaptic expression of NMDA receptors as previously suggested (Dunah et al., 2004). Further work is needed in order to determine which pathway is the one activated in the hippocampus and cortex.

In addition to dopaminergic and glutamatergic signaling, muscarinic transmission also plays an important role in ERK1/2 activation and consolidation of memory, as well as synaptic plasticity. For example, the muscarinic agonist carbachol (Cch) induces prolonged dose-dependent activation of ERK1/2 in the CA1 pyramidal neurons of mice (Rosenblum et al., 2000; Berkeley et al., 2001). In addition, both muscarinic acetylcholine receptors (mAChRs) and ERK1/2 have previously been shown to play a role in LTP and other forms of synaptic modulation (Watabe et al., 2000). In line with these reports, in the present study carbachol (Cch) induced ERK1/2 activation in hippocampal slices. Based on the results that show that D1-induced ERK1/2 activation is NMDA receptor-dependent, we further examined whether $\mathrm{mAChRs}$ use similar molecular pathways to activate ERK1/2. We found that ERK1/2 activation by $\mathrm{mAChRs}$ was NMDA receptor-independent. Moreover, we found that ERK1/2 was activated in the NR2B F1472 mice following Cch administration, but not following dopamine stimulation. This segregation between dopamine and mAChRs may imply that there are distinct mechanisms, both of which are necessary for induction of ERK1/2 and long-term memory. Whereas dopamine receptors require glutamatergic transmission 
in order to enhance and maintain LTP in the hippocampus (Frey et al., 1990, 1991; Navakkode et al., 2010), the mAChRs may induce ERK1/2 activation by cAMP and PKC (Kim et al., 1999; Rosenblum et al., 2000; Budd et al., 2001), and not via the NMDA receptor.

In conclusion, we have demonstrated that dopamine converges on the NMDA receptor and leads to phosphorylation of NR2B Y1472 which is both correlated with and necessary for ERK1/2 activation in the mature hippocampus and cortex. Malfunction of dopamine or NMDA receptors causes various types of mental disorders, such as schizophrenia. Our results, taken together with recent findings in schizophrenia patients (Kantrowitz and Javitt, 2010; Weickert et al., 2012), may imply that impairment in dopamine-induced NR2B Y1472 phosphorylation and ERK1/2 activation is involved in schizophrenia-like behavior and thus can function as targets for possible therapy.

\section{ACKNOWLEDGMENTS}

This work was supported by the European Union Seventh Framework Program EUROSPIN (Contract HEALTH-F2-2009-241498) and by the German-Israeli Foundation DIP (RO3971/1-1) for Kobi Rosenblum. The authors thank laboratory members of Kobi Rosenblum for their support and Dr. Paul Skehel for critical reading of the manuscript.

\section{SUPPLEMENTARY MATERIAL}

The Supplementary Material for this article can be found online at: http://www.frontiersin.org/journal/10.3389/fnmol.2014.00066/ abstract

\section{REFERENCES}

Abe, T., Matsumura, S., Katano, T., Mabuchi, T., Takagi, K., Xu, L., et al. (2005). Fyn kinase-mediated phosphorylation of NMDA receptor NR2B subunit at Tyr1472 is essential for maintenance of neuropathic pain. Eur. J. Neurosci. 22, 1445-1454. doi: 10.1111/j.1460-9568.2005.04340.x

Agnoli, L., and Carli, M. (2011). Synergistic interaction of dopamine D(1) and glutamate N-methyl-D-aspartate receptors in the rat dorsal striatum controls attention. Neuroscience 185, 39-49. doi: 10.1016/j.neuroscience.2011. 04.044

Bailey, C. H., Giustetto, M., Huang, Y. Y., Hawkins, R. D., and Kandel, E. R. (2000). Is heterosynaptic modulation essential for stabilizing Hebbian plasticity and memory? Nat. Rev. Neurosci. 1, 11-20. doi: 10.1038/35036191

Baker, R. M., Shah, M. J., Sclafani, A., and Bodnar, R. J. (2003). Dopamine D1 and D2 antagonists reduce the acquisition and expression of flavor-preferences conditioned by fructose in rats. Pharmacol. Biochem. Behav. 75, 55-65. doi: 10.1016/S0091-3057(03)00039-X

Barki-Harrington, L., Elkobi, A., Tzabary, T., and Rosenblum, K. (2009). Tyrosine phosphorylation of the $2 \mathrm{~B}$ subunit of the NMDA receptor is necessary for taste memory formation. J. Neurosci. 29, 9219-9226. doi: 10.1523/JNEUROSCI.566708.2009

Bear, M. F., and Abraham, W. C. (1996). Long-term depression in hippocampus. Annu. Rev. Neurosci. 19, 437-462. doi: 10.1146/annurev.ne.19.030196.002253

Belelovsky, K., Elkobi, A., Kaphzan, H., Nairn, A. C., and Rosenblum, K. (2005). A molecular switch for translational control in taste memory consolidation. Eur. J. Neurosci. 22, 2560-2568. doi: 10.1111/j.1460-9568.2005.04428.x

Berkeley, J. L., Gomeza, J., Wess, J., Hamilton, S. E., Nathanson, N. M., and Levey, A. I. (2001). M1 muscarinic acetylcholine receptors activate extracellular signalregulated kinase in CAl pyramidal neurons in mouse hippocampal slices. Mol. Cell. Neurosci. 18, 512-524. doi: 10.1006/mcne.2001.1042

Berman, D. E., Hazvi, S., Neduva, V., and Dudai, Y. (2000). The role of identified neurotransmitter systems in the response of insular cortex to unfamiliar taste: activation of ERK1-2 and formation of a memory trace. J. Neurosci. 20, 70177023.
Bernal, S. Y., Dostova, I., Kest, A., Abayev, Y., Kandova, E., Touzani, K., et al. (2008). Role of dopamine D1 and D2 receptors in the nucleus accumbens shell on the acquisition and expression of fructose-conditioned flavor-flavor preferences in rats. Behav. Brain Res. 190, 59-66. doi: 10.1016/j.bbr.2008.02.003

Bliss, T. V., and Collingridge, G. L. (1993). A synaptic model of memory: long-term potentiation in the hippocampus. Nature 361, 31-39. doi: 10.1038/361031a0

Budd, D. C., Willars, G. B., McDonald, J. E., and Tobin, A. B. (2001). Phosphorylation of the $\mathrm{Gq} / 11$-coupled $\mathrm{m} 3$-muscarinic receptor is involved in receptor activation of the ERK-1/2 mitogen-activated protein kinase pathway. J. Biol. Chem. 276, 4581-4587. doi: 10.1074/jbc.M008827200

Cannon, C. M., Scannell, C. A., and Palmiter, R. D. (2005). Mice lacking dopamine D1 receptors express normal lithium chloride-induced conditioned taste aversion for salt but not sucrose. Eur. J. Neurosci. 21, 2600-2604. doi: 10.1111/j.14609568.2005.04077.x

Chung, K. C., Shin, S. W., Yoo, M., Lee, M. Y., Lee, H. W., Choe, B. K., et al. (2000). A systemic administration of NMDA induces immediate early gene pip92 in the hippocampus. J. Neurochem. 75, 9-17. doi: 10.1046/j.1471-4159.2000.0750009

Coccurello, R., Oliverio, A., and Mele, A. (2012). Dopamine-glutamate interplay in the ventral striatum modulates spatial learning in a receptor subtype-dependent manner. Neuropsychopharmacology 37, 1122-1133. doi: 10.1038/npp.2011.296

Dunah, A. W., Sirianni, A. C., Fienberg, A. A., Bastia, E., Schwarzschild, M. A., and Standaert, D. G. (2004). Dopamine D1-dependent trafficking of striatal Nmethyl-D-aspartate glutamate receptors requires Fyn protein tyrosine kinase but not DARPP-32. Mol. Pharmacol. 65, 121-129. doi: 10.1124/mol.65.1.121

Dunah, A. W., and Standaert, D. G. (2001). Dopamine D1 receptor-dependent trafficking of striatal NMDA glutamate receptors to the postsynaptic membrane. J. Neurosci. 21, 5546-5558.

Elkobi, A., Ehrlich, I., Belelovsky, K., Barki-Harrington, L., and Rosenblum, K. (2008). ERK-dependent PSD-95 induction in the gustatory cortex is necessary for taste learning, but not retrieval. Nat. Neurosci. 11, 1149-1151. doi: $10.1038 / \mathrm{nn} .2190$

Fenu, S., Bassareo, V., and Di Chiara, G. (2001). A role for dopamine D1 receptors of the nucleus accumbens shell in conditioned taste aversion learning. J. Neurosci. 21, 6897-6904. doi: 10.1046/j.1460-9568.2003.02899.x

Frey, U., Matthies, H., Reymann, K. G., and Matthies, H. (1991). The effect of dopaminergic D1 receptor blockade during tetanization on the expression of long-term potentiation in the rat CA1 region in vitro. Neurosci. Lett. 129, 111-114. doi: 10.1016/0304-3940(91)90732-9

Frey, U., Schroeder, H., and Matthies, H. (1990). Dopaminergic antagonists prevent long-term maintenance of posttetanic LTP in the CA1 region of rat hippocampal slices. Brain Res. 522, 69-75. doi: 10.1016/0006-8993(90)91578-5

Grosshans, D. R., Clayton, D. A., Coultrap, S. J., and Browning, M. D. (2002). LTP leads to rapid surface expression of NMDA but not AMPA receptors in adult rat CA1. Nat. Neurosci. 5, 27-33. doi: 10.1038/nn779

Guerrero, C., Pesce, L., Lecuona, E., Ridge, K. M., and Sznajder, J. I. (2002). Dopamine activates ERKs in alveolar epithelial cells via Ras-PKC-dependent and Grb2/Sos-independent mechanisms. Am. J. Physiol. Lung Cell. Mol. Physiol. 282, L1099-L1107. doi: 10.1152/ajplung.00178.2001

Guzman-Ramos, K., and Bermudez-Rattoni, F. (2011). Post-learning molecular reactivation underlies taste memory consolidation. Front. Syst. Neurosci. 5:79. doi: 10.3389/fnsys.2011.00079

Guzman-Ramos, K., Osorio-Gomez, D., Moreno-Castilla, P., and BermudezRattoni, F. (2010). Off-line concomitant release of dopamine and glutamate involvement in taste memory consolidation. J. Neurochem. 114, 226-236. doi: 10.1111/j.1471-4159.2010.06758.x

Hallett, P. J., Spoelgen, R., Hyman, B. T., Standaert, D. G., and Dunah, A. W. (2006). Dopamine D1 activation potentiates striatal NMDA receptors by tyrosine phosphorylation-dependent subunit trafficking. J. Neurosci. 26, 4690-4700. doi: 10.1523/JNEUROSCI.0792-06.2006

Hooks, M. S., and Kalivas, P. W. (1995). The role of mesoaccumbens - pallidal circuitry in novelty-induced behavioral activation. Neuroscience 64, 587-597. doi: 10.1016/0306-4522(94)00409-x

Huang, Y. Y., and Kandel, E. R. (1995). D1/D5 receptor agonists induce a protein synthesis-dependent late potentiation in the CAl region of the hippocampus. Proc. Natl. Acad. Sci. U.S.A. 92, 2446-2450. doi: 10.1073/pnas.92.7.2446

Ihalainen, J. A., Riekkinen, P. Jr., and Feenstra, M. G. (1999). Comparison of dopamine and noradrenaline release in mouse prefrontal cortex, striatum and hippocampus using microdialysis. Neurosci. Lett. 277, 71-74. doi: 10.1016/S0304-3940(99)00840-X 
Inberg, S., Elkobi, A., Edri, E., and Rosenblum, K. (2013). Taste familiarity is inversely correlated with Arc/Arg3.1 hemispheric lateralization. J. Neurosci. 33, 11734-11743. doi: 10.1523/JNEUROSCI.0801-13.2013

Jenab, S., Festa, E. D., Nazarian, A., Wu, H. B., Sun, W. L., Hazim, R., et al. (2005). Cocaine induction of ERK proteins in dorsal striatum of Fischer rats. Brain Res. Mol. Brain Res. 142, 134-138. doi: 10.1016/j.molbrainres.2005.08.015

Kanterewicz, B. I., Urban, N. N., McMahon, D. B., Norman, E. D., Giffen, L. J., Favata, M. F., et al. (2000). The extracellular signal-regulated kinase cascade is required for NMDA receptor-independent LTP in area CA1 but not area CA3 of the hippocampus. J. Neurosci. 20, 3057-3066.

Kantrowitz, J. T., and Javitt, D. C. (2010). N-Methyl-D-aspartate (NMDA) receptor dysfunction or dysregulation: the final common pathway on the road to schizophrenia? Brain Res. Bull. 83, 108-121. doi: 10.1016/j.brainresbull.2010.04.006

Kaphzan, H., Doron, G., and Rosenblum, K. (2007). Co-application of NMDA and dopamine-induced rapid translation of RSK2 in the mature hippocampus. J. Neurochem. 103, 388-399. doi: 10.1111/j.1471-4159.2007.04774.x

Kaphzan, H., O'Riordan, K. J., Mangan, K. P., Levenson, J. M., and Rosenblum, K. (2006). NMDA and dopamine converge on the NMDA-receptor to induce ERK activation and synaptic depression in mature hippocampus. PLoS ONE 1:e138. doi: 10.1371/journal.pone.0000138

Kemp, N., and Bashir, Z. I. (2001). Long-term depression: a cascade of induction and expression mechanisms. Prog. Neurobiol. 65, 339-365. doi: 10.1016/S03010082(01)00013-2

Kessels, H. W., Nabavi, S., and Malinow, R. (2013). Metabotropic NMDA receptor function is required for beta-amyloid-induced synaptic depression. Proc. Natl. Acad. Sci. U.S.A. 110, 4033-4038. doi: 10.1073/pnas.1219605110

Kheirbek, M. A., Tannenholz, L., and Hen, R. (2012). NR2B-dependent plasticity of adult-born granule cells is necessary for context discrimination. J. Neurosci. 32, 8696-8702. doi: 10.1523/JNEUROSCI.1692-12.2012

Kim, J. Y., Yang, M. S., Oh, C. D., Kim, K. T., Ha, M. J., Kang, S. S., et al. (1999). Signalling pathway leading to an activation of mitogen-activated protein kinase by stimulating M3 muscarinic receptor. Biochem. J. 337(Pt 2), 275-280. doi: 10.1042/0264-6021:3370275

Kim, M. J., Dunah, A. W., Wang, Y. T., and Sheng M. (2005). Differential roles of NR2A- and NR2B-containing NMDA receptors in Ras-ERK signaling and AMPA receptor trafficking. Neuron 46, 745-760. doi: 10.1016/j.neuron.2005.04.031

Lee, F. J., and Liu, F. (2004). Direct interactions between NMDA and D1 receptors: a tale of tails. Biochem. Soc. Trans. 32, 1032-1036. doi: 10.1042/BST0321032

Lee, F. J., Xue, S., Pei, L., Vukusic, B., Chery, N., Wang, Y., et al. (2002). Dual regulation of NMDA receptor functions by direct protein-protein interactions with the dopamine D1 receptor. Cell 111, 219-230. doi: 10.1016/S0092-8674(02)00962-5

Lee, M. Y., Heo, J. S., and Han, H. J. (2006). Dopamine regulates cell cycle regulatory proteins via cAMP, $\mathrm{Ca}(2+) / \mathrm{PKC}$, MAPKs, and NF-kappaB in mouse embryonic stem cells. J. Cell. Physiol. 208, 399-406. doi: 10.1002/jcp.20674

Li, S., Cullen, W. K., Anwyl, R., and Rowan, M. J. (2003). Dopamine-dependent facilitation of LTP induction in hippocampal CA1 by exposure to spatial novelty. Nat. Neurosci. 6, 526-531. doi: 10.1038/nn1049

Ljungberg, T., Apicella, P., and Schultz, W. (1992). Responses of monkey dopamine neurons during learning of behavioral reactions. J. Neurophysiol. 67, 145-163.

Martina, M., and Bergeron, R. (2008). D1 and D4 dopaminergic receptor interplay mediates coincident $\mathrm{G}$ protein-independent and dependent regulation of glutamate NMDA receptors in the lateral amygdala. J. Neurochem. 106, 2421-2435. doi: $10.1111 /$ j.1471-4159.2008.05584.x

Matthies, H., Becker, A., Schroeder, H., Kraus, J., Hollt, V., and Krug, M. (1997). Dopamine D1-deficient mutant mice do not express the late phase of hippocampal long-term potentiation. Neuroreport 8, 3533-3535. doi: 10.1097/00001756-199711100-00023

Nabavi, S., Kessels, H. W., Alfonso, S., Aow, J., Fox, R., and Malinow, R. (2013). Metabotropic NMDA receptor function is required for NMDA receptordependent long-term depression. Proc. Natl. Acad. Sci. U.S.A. 110, 4027-4032. doi: 10.1073/pnas.1219454110

Nagai, T., Takuma, K., Kamei, H., Ito, Y., Nakamichi, N., Ibi, D., et al. (2007). Dopamine D1 receptors regulate protein synthesis-dependent long-term recognition memory via extracellular signal-regulated kinase $1 / 2$ in the prefrontal cortex. Learn. Mem. 14, 117-125. doi: 10.1101/lm.461407

Nakazawa, K., Quirk, M. C., Chitwood, R. A., Watanabe, M., Yeckel, M. F., Sun, L. D., et al. (2002). Requirement for hippocampal CA3 NMDA receptors in associative memory recall. Science 297, 211-218. doi: 10.1126/science.1071795
Nakazawa, T., Komai, S., Watabe, A. M., Kiyama, Y., Fukaya, M., ArimaYoshida, F., etal. (2006). NR2B tyrosine phosphorylation modulates fear learning as well as amygdaloid synaptic plasticity. $E M B O ~ J .25,2867-2877$. doi: 10.1038/sj.emboj.7601156

Navakkode, S., Sajikumar, S., Sacktor, T. C., and Frey, J. U. (2010). Protein kinase Mzeta is essential for the induction and maintenance of dopamine-induced long-term potentiation in apical CA1 dendrites. Learn. Mem. 17, 605-611. doi: 10.1101/lm.1991910

Pascoli, V., Besnard, A., Herve, D., Pages, C., Heck, N., Girault, J. A., et al. (2011). Cyclic adenosine monophosphate-independent tyrosine phosphorylation of NR2B mediates cocaine-induced extracellular signal-regulated kinase activation. Biol. Psychiatry 69, 218-227. doi: 10.1016/j.biopsych.2010.08.031

Riedel, G., Platt, B., and Micheau, J. (2003). Glutamate receptor function in learning and memory. Behav. Brain Res. 140, 1-47. doi: 10.1016/S0166-4328(02)00272-3

Rosenblum, K., Berman, D. E., Hazvi, S., Lamprecht, R., and Dudai, Y. (1997). NMDA receptor and the tyrosine phosphorylation of its $2 \mathrm{~B}$ subunit in taste learning in the rat insular cortex. J. Neurosci. 17, 5129-5135.

Rosenblum, K., Futter, M., Jones, M., Hulme, E. C., and Bliss, T. V. (2000). ERKI/II regulation by the muscarinic acetylcholine receptors in neurons. J. Neurosci. 20, 977-985.

Rosenblum, K., Meiri, N., and Dudai, Y. (1993). Taste memory: the role of protein synthesis in gustatory cortex. Behav. Neur. Biol. 59, 49-56. doi: 10.1016/01631047(93)91145-D

Sarantis, K., Antoniou, K., Matsokis, N., and Angelatou, F. (2011). Exposure to novel environment is characterized by an interaction of D1/NMDA receptors underlined by phosphorylation of the NMDA and AMPA receptor subunits and activation of ERK1/2 signaling, leading to epigenetic changes and gene expression in rat hippocampus. Neurochem. Int. 60, 55-67. doi: 10.1016/j.neuint.2011.10.018

Sotres-Bayon, F., Bush, D. E., and LeDoux, J. E. (2007). Acquisition of fear extinction requires activation of NR2B-containing NMDA receptors in the lateral amygdala. Neuropsychopharmacology 32, 1929-1940. doi: 10.1038/sj.npp.1301316

Stramiello, M., and Wagner, J. J. (2008). D(1/5) receptor-mediated enhancement of LTP requires PKA, Src family kinases, and NR2B-containing NMDARs. Neuropharmacology 55, 871-877. doi: 10.1016/j.neuropharm.2008.06.053

Swank, M. W. (2000). Pharmacological antagonism of tyrosine kinases and MAP kinase in brainstem blocks taste aversion learning in mice. Physiol. Behav. 69, 499-503. doi: 10.1016/S0031-9384(00)00225-0

Thiels, E., Kanterewicz, B. I., Norman, E. D., Trzaskos, J. M., and Klann, E. (2002). Long-term depression in the adult hippocampus in vivo involves activation of extracellular signal-regulated kinase and phosphorylation of Elk-1. J. Neurosci. 22, 2054-2062.

Touzani, K., Bodnar, R. J., and Sclafani, A. (2010). Acquisition of glucoseconditioned flavor preference requires the activation of dopamine D1-like receptors within the medial prefrontal cortex in rats. Neurobiol. Learn. Mem. 94, 214-219. doi: 10.1016/j.nlm.2010.05.009

Valjent, E., Corvol, J. C., Pages, C., Besson, M. J., Maldonado, R., and Caboche, J. (2000). Involvement of the extracellular signal-regulated kinase cascade for cocaine-rewarding properties. J. Neurosci. 20, 8701-8709.

Valjent, E., Pascoli, V., Svenningsson, P., Paul, S., Enslen, H., Corvol, J. C., et al. (2005). Regulation of a protein phosphatase cascade allows convergent dopamine and glutamate signals to activate ERK in the striatum. Proc. Natl. Acad. Sci. U.S.A. 102, 491-496. doi: 10.1073/pnas.0408305102

Walker, D. L., and Davis, M. (2008). Amygdala infusions of an NR2B-selective or an NR2A-preferring NMDA receptor antagonist differentially influence fear conditioning and expression in the fear-potentiated startle test. Learn. Mem. 15, 67-74. doi: $10.1101 / \mathrm{lm} .798908$

Watabe, A. M., Zaki, P. A., and O'Dell, T. J. (2000). Coactivation of beta-adrenergic and cholinergic receptors enhances the induction of long-term potentiation and synergistically activates mitogen-activated protein kinase in the hippocampal CA1 region. J. Neurosci. 20, 5924-5931.

Weickert, C. S., Fung, S. J., Catts, V. S., Schofield, P. R., Allen, K. M., Moore, L. T., et al. (2012). Molecular evidence of N-methyl-D-aspartate receptor hypofunction in schizophrenia. Mol. Psychiatry 18, 1185-1192. doi: 10.1038/mp.2012.137

Xia, Z., Dudek, H., Miranti, C. K., and Greenberg, M. E. (1996). Calcium influx via the NMDA receptor induces immediate early gene transcription by a MAP kinase/ERK-dependent mechanism. J. Neurosci. 16, 5425-5436.

Yan, Z., Feng, J., Fienberg, A. A., and Greengard, P. (1999). D(2) dopamine receptors induce mitogen-activated protein kinase and cAMP response element-binding 
protein phosphorylation in neurons. Proc. Natl. Acad. Sci. U.S.A. 96, 1160711612. doi: 10.1073/pnas.96.20.11607

Zhang, L., Lou, D., Jiao, H., Zhang, D., Wang, X., Xia, Y., et al. (2004). Cocaineinduced intracellular signaling and gene expression are oppositely regulated by the dopamine D1 and D3 receptors. J. Neurosci. 24, 3344-3354. doi: 10.1523/JNEUROSCI.0060-04.2004

Zhang, X. H., Liu, F., Chen, Q., Zhang, C. L., Zhuo, M., Xiong, Z. Q., et al. (2008). Conditioning-strength dependent involvement of NMDA NR2B subtype receptor in the basolateral nucleus of amygdala in acquisition of auditory fear memory. Neuropharmacology 55, 238-246. doi: 10.1016/j.neuropharm.2008.05.030

Conflict of Interest Statement: The authors declare that the research was conducted in the absence of any commercial or financial relationships that could be construed as a potential conflict of interest.
Received: 30 May 2014; accepted: 02 July 2014; published online: 18 July 2014. Citation: David O, Barrera I, Chinnakkaruppan A, Kaphzan H, Nakazawa T, Yamamoto $T$ and Rosenblum K (2014) Dopamine-induced tyrosine phosphorylation of NR2B (Tyr1472) is essential for ERK1/2 activation and processing of novel taste information. Front. Mol. Neurosci. 7:66. doi: 10.3389/fnmol.2014. 00066

This article was submitted to the journal Frontiers in Molecular Neuroscience. Copyright () 2014 David, Barrera, Chinnakkaruppan, Kaphzan, Nakazawa, Yamamoto and Rosenblum. This is an open-access article distributed under the terms of the Creative Commons Attribution License (CC BY). The use, distribution or reproduction in other forums is permitted, provided the original author(s) or licensor are credited and that the original publication in this journal is cited, in accordance with accepted academic practice. No use, distribution or reproduction is permitted which does not comply with these terms. 